\title{
Research on Logistics Value Chain Analysis and Competitiveness Construction for Express Enterprises*
}

\author{
Xingjian Zhou \\ School of Management, Wuhan Textile University, Research Center of Hubei Logistics Development, Wuhan, China. \\ Email:wuliuwtu@163.com
}

Received January 20 ${ }^{\text {th }}, 2013$; revised February $28^{\text {th }}$, 2013; accepted March 20 ${ }^{\text {th }}, 2013$

Copyright (C 2013 Xingjian Zhou. This is an open access article distributed under the Creative Commons Attribution License, which permits unrestricted use, distribution, and reproduction in any medium, provided the original work is properly cited.

\begin{abstract}
Through analyzing the value of the activities in the process of express delivery, the model of logistics value chain analysis (LVCA) of express enterprises is constructed. Using the model, the express enterprises can identify the key activities from the whole process of express delivery from senders to receivers, and those key activities constitute the logistics competitiveness of express enterprises. Then a model of logistics competitiveness is established, which includes four aspects: strategic location, network optimization, value-added services and performance measures. Those four aspects form the core logistics competitiveness for express enterprises.
\end{abstract}

Keywords: Logistics Value Chain; Logistics Competitiveness; Express Enterprises

\section{Introduction}

With about 30 years development, China has formed a large-scales express delivery industry. In 2008, the volume of express enterprises registration in China has more than 5000, and the express delivery industry has employed about 23.1 million people [1]. However, the competition of express markets becomes fiercer increasingly, more and more express enterprises are required to provide the services with faster and safer. A growing number of express enterprises began to develop the directservice, such as "door to door", "table to table". Furthermore, some enterprises try to shorten the delivery time, and they began to develop the faster-service, such as "next day delivery", "next morning delivery". Therefore, it's very important for express enterprises to form the core competitiveness, so as to win more customers in express market [2].

Consequently, for express enterprises, its core competitiveness is manifested in the implement "customer value strategy". Customer value strategy is a value-creating activity to win the finally success, and win customers' satisfies by creating more value for them, rather than simply improve the services qualities or service technologies [3].

Therefore, the express enterprises will focus on how to

*Sponsored by the Hubei Provincial Department of Education, and Research Center of Hubei Logistics Development. create customer demands, make the express delivery value-added, and achieve the competitive advantage. We can use the theory of Michael Porter's value chain (VC) [4] to help express enterprises to identity the key activities or business which make logistics value added in the express delivery process, and then form their core logistics competitiveness.

\section{Logistics Value Chain Analysis of Express Delivery}

\subsection{Logistics Value Chain}

Value chain is a theoretical tool of analysis the competetive advantage for an enterprise [5]. Introduction the theory to logistics area, so-called logistics value chain (LVC), refers to the chain with a series of intrinsic logistics value. Logistics value chain exists in the relationship of logistics process, from upstream to downstream. Logistics value chain reflects the nature of supply chain, and shows the origin driving force to form the supply chain. The usual sense of the "logistics contract" is a concrete form, and the value chain has been translated into supply chain as a constraint. In the traditional structure of value chain, the "logistics" activities were shown in internal logistics (i.e., industrial logistics) and external logistics (i.e., business logistics), but all of them are parts of logistics value chain [6].

In fact, logistics value chain is one part of the enter- 
prise's value chain, which includes such external logistics activities as delivery of raw materials and finished goods, and also involves such internal logistics activities as production and selling. So we can think that, in the supply chain, logistics is used to optimize and integrate the logistics resources, while logistics value chain is used to design and plan the value-added activities in the logistics process. Therefore, all those activities constitute a new chain, that is logistics value chain [7]. The "value flow" in logistics value chain is shown in Figure 1.

Logistics value chain can be used to optimize logistics system and reconstruct the logistics process of express enterprises, and then make the logistics value maximized.

The express enterprises provide the logistics services, and there are different levels of value-added activities in the process of express delivery, which includes recipient, branch transportation, transit, trunk transportation, transit again, branch transportation again, distribution, etc. [8]. If the express enterprises want to improve its competetiveness, they need the cooperation and synergy from above activities to get the maximum values. Those values come from the logistics value chain, which exist in the express delivery process and networks. The logistics value chain of express enterprises is shown in Figure 2.

\subsection{Model of Logistics Value Chain Analysis}

Value chain reflects the enterprises' history, strategy, and tactics. All these activities in the enterprises can be divided into basic activities and ancillary activities, and the basic activities are considered as the key business in the enterprises. Generally, the basic activities include internal logistics, production and management, external logistics, marketing and service, which lead to better services, and more effectiveness; ancillary activities include design of the system, information sharing between logistics activities, inventory visibility and good coordination of operation, which lead to lower costs, and more efficiency [9].

According to above value chain analysis (VCA), the activities in the logistics enterprises can be also divided into basic activities and ancillary activities. For example, the basic activities in the process of express delivery: recipients, sorting (including the packaging and receiving), transportation, and distribution. In order to achieve synergy between the four aspects of the express delivery, the express enterprises need to optimize delivery network,

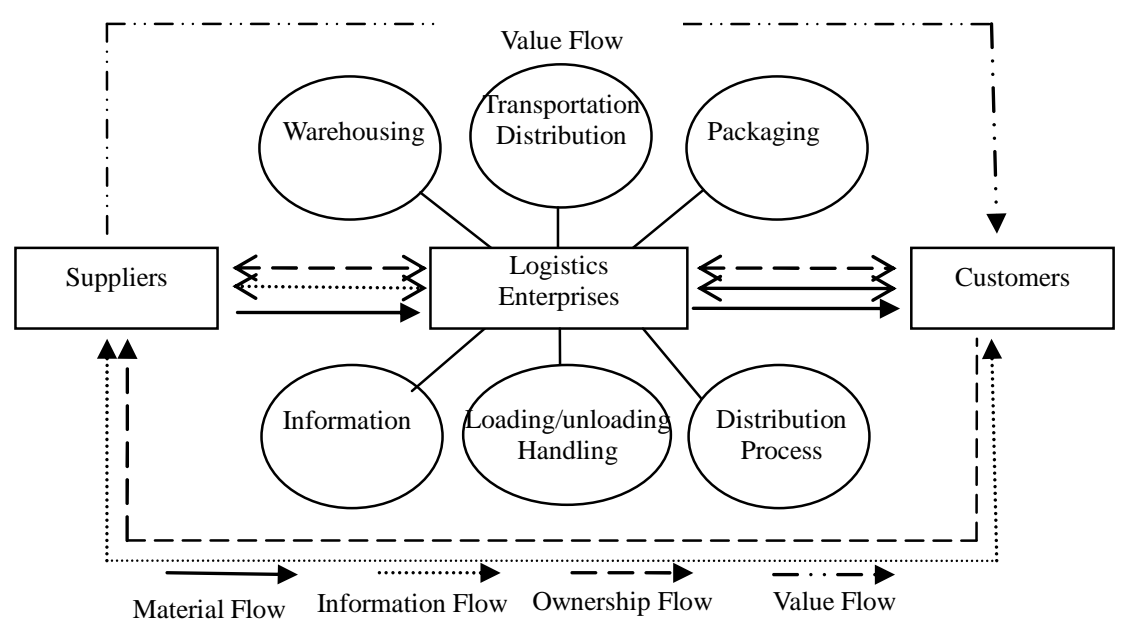

Figure 1. "Value flow" in logistics value chain.

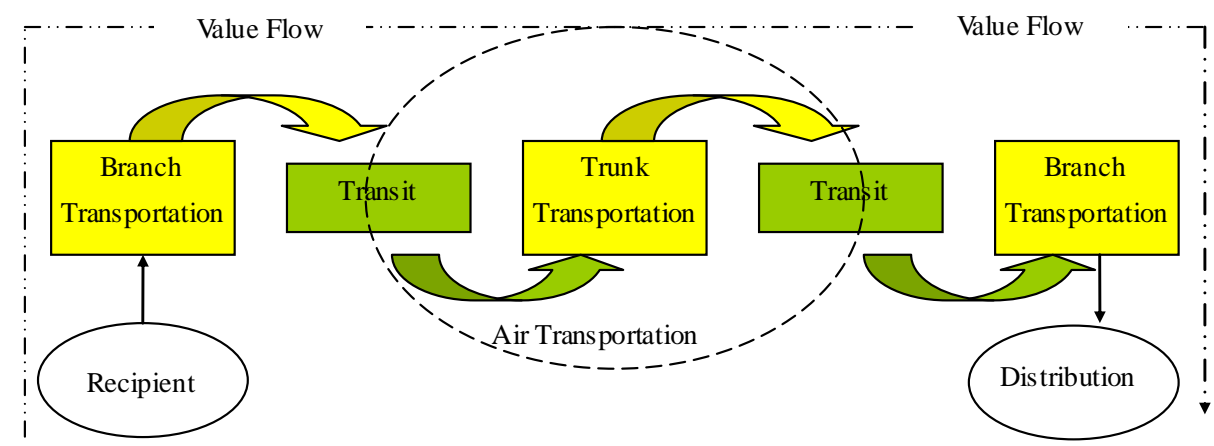

Figure 2. Logistics value chain of express delivery. 
design delivery process, etc. Ancillary activities are beyond the basic activities, and extend the basic activities, such as payment collection, e-commerce, etc., which meet and create the demands of customers.

Above logistics value chain analysis (LVCA) help the express enterprises identify the key business, find new profit growth points, make the value of both the enterprises and customers improved, and then get the core logistics competitiveness.

Specifically, for express enterprises, the basic activities include four main aspects: strategic positioning, network optimization, value-added services and performance evaluation, such as layout of logistics network, optimization of delivery process, establish of call centers, evaluation of delivery performance, and so on. The ancillary activities include two main aspects: delivery infrastructure and information platform, such as sharing the delivery information, construction the delivery network, developing e-commerce, collection payment, and so on. Basic activities are the fundamental of express enterprises to enhance competitiveness, and the source of logistics profits. Ancillary activities support the basic activities to implement successfully. All those activities create logistics value from "the third profits resource".

Through above analysis, we can build the model of logistics value chain analysis of express delivery, as shown in Figure 3.

The logistics value chain of express delivery is a dynamic process with creating logistics value for customers. In the traditional, the "customer" is the external customers of an enterprise, and the "service" is the internal "customers". In logistics value chain, combining the internal and external factors, the express enterprises improve the service quality of external and internal customers synchronously, so as to get the fully and continued advantages of internal and external resources, and then form the core logistics competitiveness.

\section{Logistics Competitiveness Model of Express Delivery}

Based on the model of logistics value chain analysis, the logistics competitiveness of express enterprises comes from the process of pursuit the logistics value. The model of logistics competitiveness for express enterprises is constructed based on the basic activities, including stra-

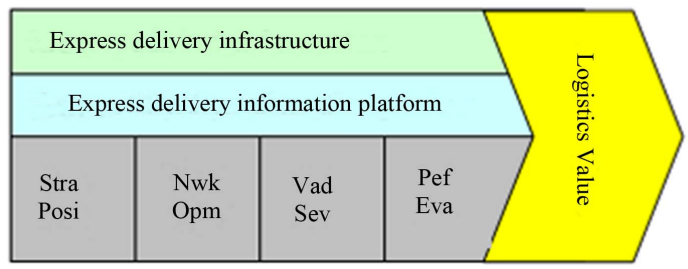

Figure 3. Model of LVCA for express delivery. tegic positioning, network optimization, value-added services and performance measures, as shown in Figure 4.

\subsection{Strategic Positioning}

Strategic positioning is a competitiveness of the accurate positioning of markets and resources. Strategic positioning refers that how to position the logistics activities in the enterprises from its strategy to structure. Business marketing strategy, procurement strategy, R \& D strategy, and logistics strategy are closely linked with each other. Logistics organizational structure, personnel structure and logistics network structure, in other words, that all logistics resources are related and integrated with the enterprises strategies and department strategies.

\subsection{Network Optimization}

Network optimization is a competitiveness of achieving synergy effect, which comes from the theory of system. Network optimization refers that how to implement the logistics strategy. The logistics enterprises need to construct a coordination mechanism between internal and external enterprises, and use the mechanism to control the total cost of logistics, service objectives, logistics ideas and cross-functional process.

\subsection{Value-Added Services}

Value-added service is a competitiveness of responding the customers' demands rapidly, which includes various kinds of business to improve customers' satisfaction. Value-added services come from the idea of logistics system. The goal of logistics system is to serve customers, and the only purpose is to create value for customers.

\subsection{Performance Evaluation}

Performance evaluation is a necessary factor so that a

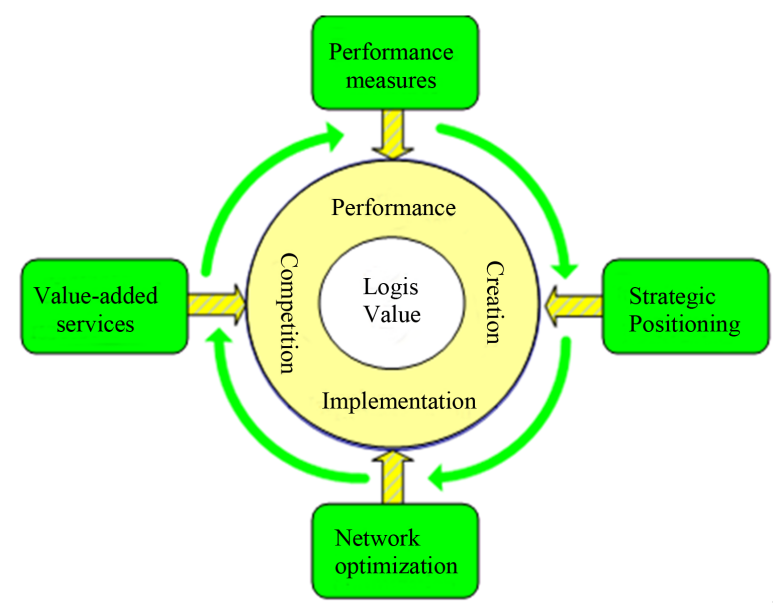

Figure 4. Logistics competitiveness model of express delivery. 
logistics system can fulfill its functions successfully. The logistics process's efficiency and effectiveness must be measurable, so that managers can control and adjust timely to ensure that the organization goals can be achieved with shorter time and lower costs. The logistics enterprises should have an internal and external "monitor mode", which will provide information for strategic positioning, network optimization and value-added services.

\section{Empirical Research: The Logistics Competitiveness for SF}

$\mathrm{SF}$ is an express enterprise and as the leader of the express delivery industry in China. The core value of SF is "FIRST" (abbreviation of faith, integrity, responsibility, service and team). The competitiveness of SF is higher than other domestic express enterprises in such aspects as network architecture, value-added services and information system. However, for SF, there are also some problems in those three areas.

\subsection{The Situation of Express Delivery for SF}

\subsubsection{Express Delivery Network}

The network of air transportation. At present, SF has own cargo aircrafts and airlines, but the coverage of shipping lines is small and the loading rate is low. Therefore, the delivery volume is not balanced, and lead to high logistics costs.

The network of road transportation. SF uses information technology to position the vehicles, and ensure the process of road transportation is smooth and effective. However, in current, the road transportation network is still unable to meet the increasing of express delivery, and the loading rate of road transportation is also low.

The process of express delivery. The delivery speed at the start and the end of express delivery is slow, because SF does not pay more attention to the links of different parts. SF spent more time in distribution, which leads to low efficiency.

\subsubsection{Value-Added Services}

Marketing homogenization. The marketing methods and means of SF are similar with other express enterprises, and imitate each other.

Marketing activities single. SF's marketing activities are not the target and lacking of innovation. Service marketing and knowledge marketing are used to maintain customer relationships, and then SF failed to develop a variety of activities based on characteristics of the VIPs.

Important clients marketing system. SF did litter to construct the VIPs marketing system, the marketing organizations and staffs are insufficient, and the marketing policy and design are not reasonable.

\subsubsection{Information Systems}

Scalability. Usually, a common demand of the information system or a business function changes will cause to modifications of a number of information subsystems in a wide range.

Synergies. The information subsystems of SF are relative independent, which form the isolated islands of information. The sharing capability of information is weak.

\subsection{Logistics Competitiveness Model of SF}

Based on above problems for SF, the logistics competetiveness model of SF is constructed from four aspects: SF's strategic positioning, SF's network optimization, SF's value-added services, and SF's performance evaluation.

\subsubsection{SF's Strategic Positioning}

"FIRST" is the strategic positioning of SF. Network optimization and value-added services are two important strategies. So the strategic positioning of SF combines those two strategies, through optimization of the express delivery network based on providing value-added services to add the logistics value in the different levels of customers' demands.

\subsubsection{SF's Network Optimization}

SF need to optimize the air transportation network and road transportation network based on logistics value chain. The network optimization is used to integrate variety resources of express delivery in order to get the synergy effects, form the coordination mechanisms, and achieve the goal of controlling total cost of delivery, services levels, process optimization and reconstruction.

\subsubsection{SF's Value-Added Services}

SF should provide value-added services with a variety of marketing methods, which is an important way to improve customers' satisfaction. SF need to use network to provide faster and more flexible delivery service, so as to meet and create customers' demand constantly.

\subsubsection{SF's Performance Evaluation}

SF should establish a measurable evaluation system and process of express delivery, which can be used to control and adjust the strategic positioning, network optimization and value-added services to achieve goals with the manner of efficiency and effectiveness.

\subsection{Characters of Logistics Competitiveness for SF}

In the model of logistics value chain analysis, the four basic activities, strategic positioning, network optimization, value-added services and performance evaluation, 
each include a series of indicators. Good or bad indicators show that the express enterprises have or haven't the competitive advantages comparative to other competitors. Those indicators have a broad applicability, and provide an important basis for SF to find the direction to improve its logistics competitiveness.

For SF, the characters of logistics competitiveness and the indicators of logistics value chain are shown in Table $\mathbf{1 .}$

\section{Conclusions}

The core competitiveness is a system of certain advantages, abilities or knowledge for the enterprises, and shown as the key activities or unique business in the enterprises. The core competitiveness is in relation to the enterprises' surviving and development, and it can make the enterprises stronger than other competitors. The

Table 1. Characters of logistics competitiveness.

\begin{tabular}{|c|c|c|c|}
\hline \multicolumn{4}{|c|}{ Strategic Positioning } \\
\hline Strategy & Network & Supply chain & Organization \\
\hline $\begin{array}{c}\text { High level of } \\
\text { basic services, } \\
\text { integration of } \\
\text { internal process, } \\
\text { market } \\
\text { positioning }\end{array}$ & $\begin{array}{l}\text { Establishment of } \\
\text { distribution } \\
\text { centers and } \\
\text { nodes, providing } \\
\text { solutions }\end{array}$ & $\begin{array}{l}\text { Partners, strategic } \\
\text { positioning, } \\
\text { organizations } \\
\text { expand, influence }\end{array}$ & $\begin{array}{c}\text { license, process, } \\
\text { learning, } \\
\text { dynamic, team } \\
\text { loyalty, } \\
\text { possibility }\end{array}$ \\
\hline \multicolumn{4}{|c|}{ Network Optimization } \\
\hline Cooperation & $\begin{array}{l}\text { Information } \\
\text { sharing }\end{array}$ & Standardization & Discipline \\
\hline $\begin{array}{c}\text { Specialized tasks, } \\
\text { criteria, } \\
\text { distribution }\end{array}$ & $\begin{array}{l}\text { Information } \\
\text { exchange, } \\
\text { agreement and } \\
\text { methods }\end{array}$ & $\begin{array}{l}\text { Standard } \\
\text { processes, } \\
\text { industry standards }\end{array}$ & $\begin{array}{c}\text { Predictability } \\
\text { and accuracy } \\
\text { of results, } \\
\text { pay system }\end{array}$ \\
\hline $\begin{array}{l}\text { Information } \\
\text { technology }\end{array}$ & $\begin{array}{l}\text { Information } \\
\text { exchange }\end{array}$ & Simplify & \\
\hline $\begin{array}{l}\text { IT innovation, } \\
\text { integration }\end{array}$ & $\begin{array}{l}\text { Technology, ease } \\
\text { or difficult }\end{array}$ & $\begin{array}{l}\text { Restructuring, } \\
\text { modular }\end{array}$ & \\
\hline \multicolumn{4}{|c|}{ Value-added Services } \\
\hline Idea & Ability to adapt & Customer & Flexible \\
\hline $\begin{array}{l}\text { Customer service, } \\
\text { satisfaction, } \\
\text { success }\end{array}$ & $\begin{array}{l}\text { Synchronization, } \\
\text { order execution }\end{array}$ & $\begin{array}{l}\text { Comprehensive } \\
\text { services, logistics } \\
\text { channels }\end{array}$ & $\begin{array}{c}\text { Procedures, } \\
\text { extension, } \\
\text { lateral supply }\end{array}$ \\
\hline \multicolumn{4}{|c|}{ Performance Evaluation } \\
\hline $\begin{array}{l}\text { Functional } \\
\text { assessment }\end{array}$ & Contrast & $\begin{array}{c}\text { Process } \\
\text { evaluation }\end{array}$ & \\
\hline Range, accuracy & $\begin{array}{l}\text { Internal, } \\
\text { cross-industry }\end{array}$ & $\begin{array}{l}\text { Costs, customers, } \\
\text { channels }\end{array}$ & \\
\hline
\end{tabular}

competitiveness of key activities or business and the management team leadership constitute the core competitiveness, and the core competitiveness is the essential part and fundament for the development of the enterprises.

The express enterprises provide high level services to meet customers' demands, develop the customer markets constantly, and then get the chance of growing and being stronger. There are a number of activities in the process of express delivery, but the different activity contributes the different value to the whole process. Through construction the model of logistics value chain analysis, the key activities of express delivery can be identified, which constitute the logistics competitiveness for the express enterprises. Then a model of logistics competitiveness is established, which involves four factors: strategic positioning, network optimization, value-added services and performance evaluation. The model helps the express enterprises to form the core logistics competitiveness.

\section{REFERENCES}

[1] X. Y. Xu, "Report of the Development of Express Delivery in Chian," China Social Sciences Publishing House, Beijing, 2009.

[2] D. P. Wang and Y. F. Yang, "Analysis of the Competition of the Express Market in China,” Social Science of Beijing, Vol. 48, No. 2, 2009, pp. 10-15.

[3] C. B. Jiang, "Analysis of Market Opportunities for Chinese Private Express Service,” Logistics Sci-Tech, Vol. 32, No. 8, 2009, pp. 79-81.

[4] M. Port, “Competitive Advantage,” Hua Xia Press, Beijing, 1997.

[5] X. J. Zhou, "Logistics: From Supply Chain to Value Chain,” Logistics Sci-Tech, Vol. 30, No. 12, 2007, pp. 48-49.

[6] X. J. Zhou and Q. N. Zhang, "Research on Construction and Generation of Logistics Value Chain," China Business and Market, Vol. 24, No. 4, 2010, pp. 26-29.

[7] X. J. Zhou and C. H. Huang, "Value Chain Alliance of Logistics Enterprises Based on Core Competition," Journal of Wuhan University of Science and Engineering, Vol. 20, No. 9, 2007, pp. 79-81.

[8] L. Ma and J. Tang, "Value Chain Analysis and Application of Express Enterprises,” Commercial Times, Vol. 22, No. 24, 2010, pp. 88-89.

[9] X. J. Zhou, J. Z. Li and S. A. Xie, "Optimization of Logistics Value Chain for Cluster Supply Chain,” China Business and Market, Vol. 25, No. 4, 2011, pp. 34-37. 